Supplement of Atmos. Chem. Phys. Discuss., 15, 28793-28813, 2015

http://www.atmos-chem-phys-discuss.net/15/28793/2015/

doi:10.5194/acpd-15-28793-2015-supplement

(C) Author(s) 2015. CC Attribution 3.0 License.

(c) (i)

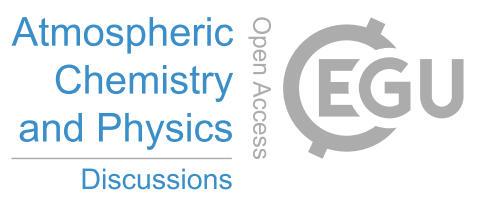

Supplement of

\title{
Dominance of brown carbon in aerosol emissions from burning of boreal peatlands
}

\section{R. K. Chakrabarty et al.}

Correspondence to: R. K. Chakrabarty (chakrabarty@wustl.edu)

The copyright of individual parts of the supplement might differ from the CC-BY 3.0 licence. 
Fuel Collection and Preparation: The peats we used in this study were from two geographic sources: Siberia, Russia, and Alaska, USA. Alaskan peat samples used in this study were from the upper $10 \mathrm{~cm}$ of soils within black spruce (Picea mariana) forests, collected and stored as solid pedons to minimize disturbance to soil physical characteristics subsequent to collection. Alaska peat samples were stored below $0^{\circ} \mathrm{C}$ following collection and were insulated/refrigerated during transport and shipment. Siberian samples used in this study were collected from the upper $10 \mathrm{~cm}$ of soil in bogs dominated by Sphagnum and cottongrass (Eriophorum). Following collection, Siberian samples were dried to constant weight at $105^{\circ} \mathrm{C}$ for transport to the Desert Research Institute per USDA Animal and Plant Health Inspection Service (APHIS) permit requirements.

Alaskan samples were dried to constant weight at $100^{\circ} \mathrm{C}$ prior to preparation for combustion. Then, each peat sample was individually rewetted using deionized water to a moisture content of $25 \%$ by mass, then stored in vapor-tight containers at $4^{\circ} \mathrm{C}$ until approximately one day prior to combustion, when samples were removed from refrigeration and allowed to equilibrate with ambient temperature before being placed in the combustion vessel and ignited.

Fuel-based emission factor calculation. Fuel-based emission factor (EF) is the mass of a compound released per mass of fuel consumed, and is related to the amount of carbon in the fuel as:

$E F_{j}=\frac{M_{j}}{M_{\text {fuel }}}=\frac{M_{j}}{C_{a s h}+\sum_{i} C_{i}} X_{c, \text { fuel }}=\frac{M_{j}}{\sum_{i} C_{i}}\left(\frac{\sum_{i} C_{i}}{C_{a s h}+\sum_{i} C_{i}}\right) X_{c, \text { fuel }}=\frac{M_{j}}{\sum_{i} C_{i}}\left(X_{c, \text { fuel }}-\frac{M_{\text {ash }}}{M_{\text {fuel }}} X_{c, \text { ash }}\right)$

$E F_{j}$ : emission factor of species $j$

$M_{\text {fuel: }}$ : mass of the fuel burned

$M_{j}$ : mass of the species $j$ emitted

$C_{\text {ash }}$ : carbon mass in ash

$C_{i}$ : carbon mass in every combustion product $i\left(\mathrm{CO}_{2}\right.$, $\mathrm{CO}$, etc., including species $\left.j\right)$

$x_{c, f u e l}$ and $x_{c, \text { ash }}$ : carbon mass fraction in fuel and ash, respectively 